\title{
Destination Satisfaction in Senior Tourism: A Case Study
}

\section{María-José Gómez-Aguilella ${ }^{a}$, John Cardiff ${ }^{b}$}

âUniversidad Jaume I, Castellón, Spain; Email aguilelm@uji.es, 'bocial Media Research Group, Technological University Dublin, Ireland; Email: john.cardiff@ tudublin.ie

\begin{abstract}
In this paper, we present a study which analyzes the experiences of elderly people, when travelling as tourists to specific destinations. With this specific profile we searched results that help us to determine their prospects in tourism. The research is also focused on a specific country, Ireland, although cross-cultural studies are being developed in Spain. The surveys are carried out in three touristic places chosen because of their popularity with our target audience. We conduct a survey in which we elicited the expectations that exist before visiting that destination regarding the perceived reputation of that tourist destination and of the quality of the services offered. These aspects also relate to the degree of hospitality of its inhabitants. This allows us to determine the tourist experience in the destination, focusing on the emotions of the visitor to the destination and of the level of disconnect from everyday life that is achieved. We establish the degree to which their feelings on the destination are discussed in social networks - an important point as this group have not traditionally used social media to a significant degree. We try to establish by means of a quantitative study the tourist profile of these people of advanced age, which is an area of research that has received little attention to date. For this reason, the study reveals knowledge of a new visitor profile in tourist destinations, determined by the experience lived.
\end{abstract}

Keywords: senior tourism, expectations, reputation, tourist experience

\section{Introduction}

The impact of tourism in the economic growth of countries and local destinations has been widely confirmed (Song, Dwyer, \& Cao, 2012; Tugcu, 2014; Webster \& Ivanov, 2014). Tourism destinations are central to the tourism industry (Kozak \& Rimmington, 1999). The centre for Strategic and International Studies (2000) describes global ageing as the 
challenge of the new millennium (Batra, 2009). Obviously, from an operator or destination perspective, repeat visits have been intuitively used as an indicator of the positive perception of the "product" in question, with repeat purchase indicating a positive attitude (Oppermann 2000).

The impact of perceptions of attributes of products and service on satisfaction has received considerable attention in the literature (e.g., Baker et al. 2002; Berry, Seiders, and Grewal 2002; Bitner 1990; Oliver 1993; Lemon \& Verhoef 2016). This is not to say that there is not some anecdotal evidence and/or intuitive wisdom that some people return to the same destination over and over again (Oppermann 2000). Prior research has suggested that the customer's assessment of an experience influences key outcomes such as customer satisfaction (Lemon \& Verhoef 2016) and recent research has also focused on the value of relative metrics (e.g., satisfaction relative to competitors) as potential good predictors of customer behavior (Keiningham et al. 2015).

The characteristics of senior travelers have become an important area of interest because of the market size and its potential for growth (Horneman, Carter, Wei, \& Ruy, 2002). Senior or mature travelers are already important to the tourism industry, and they will grow in importance as the segment grows in size and wealth (Reece, 2004). Pleasure travel has been found to be an important issue positively affecting the quality of life of seniors. Although in most developed countries the relationship between quality of life and tourism for seniors has been investigated, the issue has not been examined widely outside this sector (Lee \& Tideswell, 2005).

It is helpful to understand how customer experience is related to more focused constructs, such as customer satisfaction and service quality. Customer satisfaction could be one of the components of customer experience, focusing on the customer's cognitive evaluation of the experience (Lemon \& Verhoef 2016). Dramatic improvements in health care and life expectancy have produced rapid growth in the world's senior population. At the end of the twentieth century, 11 percent of the world's population was aged 60 or above, and it is estimated that 20 percent will be 60 years or older by 2050 (United Nations Population Division, 1998, cited in Hall, 2006:12-13). The study in marketing is an incipient area of investigation in tourism that must be thoroughly explored in order to understand the complex environment in which tourism firms and destinations operate (Zeng \& Gerritsen 2014).

The objective of this study is to analyse the interaction between three key variables: expectations, experience and engagement. Related to satisfaction and social media in relation to a specific tourists destinations. We test our hypotheses in the context of three tourist locations in Ireland: Waterford, Bray and Dun Laoghaire, which are popular tourist destinations for elderly people. Surveys were conducted which were analysed using 
structural equation modelling. All points of view help us in the development of the project for the future. A more in-depth analysis can be found (Gómez-Aguilella, 2018).

This paper is organized as follows. In Section 2 we describe the satisfaction in senior tourism. In Section 3 we present our model and hypotheses. Our method, and analysis of the outcomes of the survey are described in Section 4. Finally, Section 5 presents our conclusions and limitations.

\section{Satisfaction in Senior Tourism}

The aging population in many industrialized countries draws attention from the tourism industry mainly because of its substantial size, increasing purchasing power and more time available for travel after retirement (Esichaikul, 2012). The senior market has been thus cited as one of the most important consumer segments of the tourism industry. (Shoemaker, 2000; Bai et al., 2001; Horneman et al., 2002; Jang and Wu, 2006). Understanding the travel motivations and behavior of elderly people is fundamental to travel businesses that compete for this potential growth market (Crompton, 1979; Jang and $\mathrm{Wu}, 2006)$. Customer satisfaction has been the dominant customer feedback metric for years, and marketing and consumer researchers have conducted thousands of studies on the antecedents of satisfaction, the measurement of customer satisfaction(in specific contexts), and the behaviour a land financial consequences of customer satisfaction (Bolton and Drew 1991).

To identify the traveler profiles of the elderly, Anderson and Langmeyer (1982) examined two senior groups and reported that both over-50 and under-50 groups are likely to take pleasure trips for rest and relaxation and for visiting family and relatives, but over-50 groups are more likely to visit historical sites. Javalgi et al. (1992) revealed that non-seniors are a better-educated group than seniors and are more likely to engage in a detailed information search process before making a purchase decision (Esichaikul 2012). In terms of market potential, people older than age 65 constitute an important market segment because they have discretionary income and time to travel (Javalgi, Thomas, \& Rao, 1992; Brewer, Poffley \& Pederson, 1995; Moscardo \& Green, 1999; Moisey \& Bichis, 1999). The senior market for persons aged 55 and older possesses a relatively large share of all discretionary dollars (Blazey, 1987; Javalgi et al., 1992).

In promoting tourism, it is also important that visitors receive a high quality experience or a high level of satisfaction from their holiday along with other tourism experiences which are associated with visitors' perceptions (Sharma and Dyer, 2012). Understanding the travel requirements of senior tourists will be useful for travel planners and marketers to design 
specific market strategies and to adapt tourist products to the potential needs of senior tourists (Esichaikul, 2012). In so doing, their level of satisfaction will be increased.

\section{Hypotheses}

Anderson, Fornell and Mazvacheryl (2004) have investigated the long-term effects of customer satisfaction and concluded that satisfied consumers make recommendations to others, therefore securing future income (Kobylanski, 2012). We start from the assumptions as postulations made from the data. These serve as the basis for initiating the research or argumentation (Gómez-Aguilella, 2018). Users of social networks that are subject to information influence are expected to show a greater need to acquire information and guidance from contacts with greater knowledge (Chu \& Kim, 2011). Most models on tourism destination choice include a reference to the importance of previous experience on the destination choice process, often symbolized by a feedback loop after the actual destination experience into the evaluative stages of future destination decisions (e.g., Chon 1990; Mansfeld 1992; Woodside and Lysonski 1989). Therefore, it is argued that:

\section{H1: Expectations of Satisfaction has a direct influence on Experience of Satisfaction}

Woodside and Lysonski's (1989) model of traveler destination choice included previous destination experience in the traveler's variables that influence destination awareness as well as traveler destination preferences (Oppermann 2000). This facilitates their engagement in the user-generated contents of social networks (Chu \& Kim, 2011). The benefits of travel for seniors include a change in everyday routine as well as an opportunity to gain new experiences (Batra, 2009). Therefore, it is proposed that:

\section{H2: Experience of Satisfaction has a direct influence on Engagement}

Laroche et al. (2012) revealed that social networking communities promote shared awareness, society's obligation, rites and traditions, trust, and customer loyalty. A year later, Brodie et al (2013) specified the reach of consumers in online participation suggesting that consumers with a good level of engagement present greater loyalty, empowerment, connection, emotional attachment, trust, and above all satisfaction (Gómez-Aguilella \& Cardiff, 2019). These effects have consistently been shown in customer satisfaction research at both the individual and aggregate levels (e.g., Bolton and Drew 1991; Rego, Morgan, and Fornell 2013; Verhoef and Van Doorn 2008). Bolton and Lemon (1999) show that prior experience influences current satisfaction, which in turn influences future usage (Lemon \& Verhoef 2016). In the marketing literature, but also the tourism literature, repeat purchase and/or visitation often is taunted as something to be desired (Oppermann 2000). 
Furthermore, destination "familiarity has been proposed as both a positive and negative factor in image evaluation. Mostly it has been associated with a more realistic impression of destination based on past experience" (MacKay and Fesenmaier 1997, p. 543). Klenosky (2002) has shown that before tourists make their travel decision, they formulate a more positive affective destination image when the destination-related emotions match their motives and the benefits pursued. Based on these findings, it is argued that:

\section{H3: Engagement has a direct influence on New Expectations of Satisfaction}

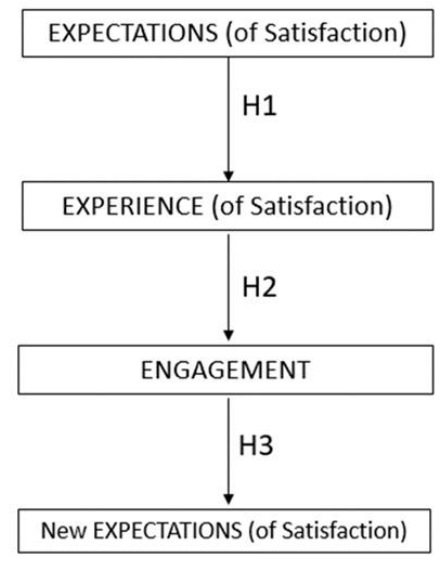

Figure 1: Model

\section{Research method, results and analysis}

Table 1. Measuring scales

\begin{tabular}{|c|c|c|}
\hline Variable & Number items & References \\
\hline Expectations (of satisfaction) & 10 & $\begin{array}{l}\text { Baloglu and McCleary, 1999, Echtner and } \\
\text { Ritchie, 1991; Beerli and Martín, 2004, } \\
\text { Gallarza et al., 2002; Kim and Richardson, } \\
\text { 2003; Beerli and Martín, } 2004 .\end{array}$ \\
\hline Experience (of satisfaction) & 15 & $\begin{array}{l}\text { D. Buhalis and A. Amaranggana, 2015) DiCicco- } \\
\text { Bloom and Crabtree 2006; Jordan and Gibson, } \\
\text { 2004; Finn et al. 2000; Patton and } \\
\text { Cochran,2002. }\end{array}$ \\
\hline Engagement & 15 & $\begin{array}{l}\text { Nunnally and Bernstein, 1994, Sprott, Czellar } \\
\text { \& Spangenberg, } 2009\end{array}$ \\
\hline
\end{tabular}


We conducted our studies on a specific country, Ireland. The surveys are carried out in three touristic places: Waterford, Bray and Dun Laoghaire, which are popular tourist destinations for elderly people. The study was conducted over one month (between AprilMay 2019).

Regarding the survey, we collected a total of 75 valid questionnaires from visitors to Waterford, Bray and Dun Laoghaire, in Ireland. The participants were presented with a set of questions related to each of the variables being analysed. Participants were asked to express their opinions by indicating their position on each question on a scale anchored at 1 (completely disagree) to 5 (completely agree).

In order to design these questions properly, we followed the approach of several authors who have proven the goodness of the scales used in previous researches (see Table 1). Concretely, for expectations (of satisfaction): Baloglu and McCleary, 1999; Echtner and Ritchie, 1991; Gallarza et al., 2002; Kim and Richardson, 2003; Beerli and Martín, 2004. For experience (of satisfaction): D. Buhalis and A. Amaranggana, 2015) DiCicco-Bloom and Crabtree 2006; Jordan and Gibson, 2004; Finn et al. 2000; Patton and Cochran,2002. And for engagement: Nunnally and Bernstein, 1994, Sprott, Czellar and Spangenberg, 2009.

Table 1 records the measuring scales for each of the three variables and statistics related to the principal demographic characteristics of the participants are summarised in Table 2 . The analysis of the data obtained in the questionnaires demonstrates the hypothesis and the relationships between variables. From the measurement of the variables (expectation, experience and engagement) and the number of items used for each scale, as well as the references used, the instrument was validated by first contrasting the model with a confirmatory factor analysis structural equation.

Table 2. Sample Characteristics

\begin{tabular}{lll}
\hline \multicolumn{1}{c}{ Demographic variables } & \multicolumn{1}{c}{ Description and Percentage } & \\
\hline Age & $56-65: 83 \%$ & $65+: 17 \%$ \\
\hline Gender & Male: $63 \%$ & Female: $37 \%$ \\
\hline Education level & University: $25 \%$ & Primary: $17 \%$ \\
& Professional training: 26\% & Without studies: $2 \%$ \\
& Secondary: $30 \%$ & \\
\hline Main occupation & Employed (including self- & Stopped: $0 \%$ \\
& $\begin{array}{l}\text { employed) } 57 \% \\
\text { Retired: } 28 \%\end{array}$ & Student: $0 \%$ \\
& Work at home: $15 \%$ & \\
\hline Location & Ireland: $100 \%$ & \\
\hline
\end{tabular}


Our results are shown in Table 3. It has been demonstrated that there is a strong relationship between the variables.

Table 3. Variable and average

\begin{tabular}{cc}
\hline Variable & Average rating scale Likert \\
\hline Expectations (of satisfaction) & 3.5 \\
Experience (of satisfaction) & 2.82 \\
Engagement & 2.7 \\
\hline
\end{tabular}

While the qualtities of data available for analysis were quite small, the findings of hypotheses result in positive feedback (Table 4).

Table 4. Relationships in model

\begin{tabular}{ccl}
\hline $\mathbf{H}$ & \multicolumn{1}{c}{ Relation } & Results \\
\hline $\mathrm{H} 1:$ & Expectations $\rightarrow$ Experience & accepted \\
$\mathrm{H} 2:$ & Experience $\rightarrow$ Engagement & accepted \\
$\mathrm{H} 3:$ & Engagement $\rightarrow$ New Expectations & accepted \\
\hline
\end{tabular}

\section{Conclusions and limitations}

When destinations then associate sociodemographic, lifestyle, or other variables with the individual tourist loyalty types, one hopefully arrives at distinct categories especially with respect to their choice of information sources. In turn, this will allow destination to specifically target the desired loyalty types (Oppermann 2000).

While the results of this study cannot be generalized due to the limited geographical coverage both with respect to origin and destination and due to the low response rate, this exploratory study does suggest that the behavioral measure of loyalty by itself can be a reasonable or even good predictor of future tourism destination choice. It certainly purports the notion that past experience has an influence on future behavior in a tourism destination choice context (Oppermann 2000). 
A possible limitation of this research is that it focused mainly on data collected from Irish seniors and is not representative of the total senior pleasure tourists in Ireland. Another possible limitation lies in the fact that the research based on the selected literature focused only on three variables: expectatives, experience and engagement. Further study could discriminate among nationalities and gender, as travel behavior and travel experience for different nationalities and genders may differ.

\section{Acknowledgement}

The work of the first author was supported by a grant from the Fundación Balaguer Gonel Hermanos.

\section{References}

Anderson, B. B., \& Langmeyer, L. (1982). The under-50 and over-50 travelers: A profile of similarities and differences. Journal of Travel Research, 20(4), 20-24.

Bai, B., Jang, S. S., Cai, L. A., \& O'leary, J. T. (2001). Determinants of travel mode choice of senior travelers to the United States. Journal of Hospitality \& Leisure Marketing, 8(3-4), 147-168.

Batra, A. (2009). Senior pleasure tourists: examination of their demography, travel experience, and travel behavior upon visiting the Bangkok metropolis. International Journal of Hospitality \& Tourism Administration, 10(3), 197-212.

Bigne, E., Ruiz, C., Andreu, L., \& Hernandez, B. (2013). The role of social motivations, ability, and opportunity in online know-how exchanges: evidence from the airline services industry. Service Business, 9(2), 209-232

Bolton, Ruth N and James H. Drew (1991), “A Multistage Model of Customers' Assessment of Service Quality and Value,” Journal of Consumer Research, 17 (4), 375 -84.

Brewer, K. P., Poffley, J. K., \& Pederson, E. B. (1995). Travel interests among special seniors: Continuing care retirement community residents. Journal of Travel and Tourism Marketing, 4(2), 93-98

Blazey, M. A. (1991). Travel and retirement status. Annuals of Tourism Research, 19, 771-853.

Chu, S. C., \& Kim, Y. (2011). Determinants of consumer engagement in electronic word-of-mouth (eWOM) in social networking sites. International journal of Advertising, 30(1), 47-75.

Crompton, J. L. (1979). Motivations for pleasure vacation. Annals of tourism research, 6(4), 408-424.

Esichaikul, R. (2012). Travel motivations, behavior and requirements of European senior tourists to Thailand. PASOS. Revista de Turismo y Patrimonio Cultural, 10(2), 47-58. 
Gómez-Aguilella, M. J. (2018). Comunicar l'art a l'educació secundària. El projecte second round (Doctoral dissertation, Universitat de València).

Gómez-Aguilella, M. J. \& Cardiff, J. (2019). The Importance of Engagement on Social Media Platforms: A Case Study. Studies in Educational Management (1) 1-7.

Buhalis, D., \& Costa, C. (Eds.). (2006). Tourism management dynamics: trends, management and tools. Routledge.

Horneman, L., Carter, R. W., Wei, S. \& Ruy, H. (2002). Profiling the senior traveler: An Australian perspective. Journal of Travel Research, 41, 23-37.

Jang, S. S., \& Wu, C. M. E. (2006). Seniors' travel motivation and the influential factors: An examination of Taiwanese seniors. Tourism management, 27(2), 306-316.

Javalgi, R. G., Thomas, E. G., \& Rao, S. R. (1992). Consumer behavior in the U.S. pleasure travel marketplace: An analysis of senior and nonsenior travelers. Journal of Travel Research, 31, 1419.

Keiningham, Timothy L., Bruce Cooil, Edward C. Malthouse, Alexander Buoye, Lerzan Aksoy,ArneDeKeyser,etal.(2015), "PerceptionsareRelative: An Examination of the Relationship Between Relative Satisfaction Metrics and Share of Wallet," Journal of Service Management, 26 (1), $2-43$.

Kozak, M., \& Rimmington, M. (1999). Measuring tourist destination competitiveness: conceptual considerations and empirical findings. International Journal of Hospitality Management, 18(3), 273-283.

Klenosky, D.B. (2002). The "pull" of tourism destinations: A means-end investigation. Journal of Travel Research, 40(4), 396-403.

Laroche, M., Habibi, M.R., Richard, M.-O. \& Sankaranarayanan, R. (2012). The effects of social media based brand communities on brand community markers, value creation practices, brand trust and brand loyalty. Computers in Human Behavior 28(5): 1755-1767.

Lee, S. H., \& Tideswell, C. (2005). Understandind attitudes towards leisure travel and the constraints faced by senior Koreans, Journal of Vacation Marketing, 11, 249-263.

Lemon, K. N., \& Verhoef, P. C. (2016). Understanding customer experience throughout the customer journey. Journal of marketing, 80(6), 69-96.

Moisey, R. N., \& Bichis, M. (1999). Psychographics of the senior nature tourists: The Katy Nature Trail. Tourism Recreation Research, 24(1), 69-76.

Moscardo, G., and Green D. (1999). Age and Activity Participation on the Great Barrier Reef. Tourism Recreation Research, 24(1), 57-68.

Oppermann, M. (2000). Tourism destination loyalty. Journal of travel research, 39(1), 78-84.

Reece, W. S. (2004). Are senior leisure travelers different? Journal of Travel Research, 43(1), 11-18. 
Sharma, B., \& Dyer, P. (2012). A longitudinal study of the residents' perceptions of tourism impacts using data from the sunshine coast Australia. PASOS. Revista de Turismo y Patrimonio Cultural, 10(2), 37-46.

Shoemaker, S. (2000). Segmenting the mature market: 10 years later. Journal of Travel Research, $39(1), 11-26$.

Song, H., Dwyer, L., Li, G., \& Cao, Z. (2012). Tourism economics research: A review and assessment. Annals of Tourism Research, 39(3), 1653-1682.

Stylos, N., Vassiliadis, C. A., Bellou, V., \& Andronikidis, A. (2016). Destination images, holistic images and personal normative beliefs: Predictors of intention to revisit a destination. Tourism Management, 53, 40-60.

Tugcu, C. T. (2014). Tourism and economic growth nexus revisited: A panel causality analysis for the case of the Mediterranean Region. Tourism Management, 42(3), 207-212.

Webster, C., \& Ivanov, S. (2014). Transforming competitiveness into economic benefits: Does tourism stimulate economic growth in more competitive destinations?. Tourism Management, 40(1), 137-140.

Zeng, B., \& Gerritsen, R. (2014). What do we know about social media in tourism? A review. Tourism Management Perspectives, 10, 27-36 